\title{
Genome-wide analysis of alternative splicing in cow: implications in bovine as a model for human diseases Elsa Chacko ${ }^{1}$ and Shoba Ranganathan*1,2
}

Addresses: ${ }^{1}$ Department of Chemistry and Biomolecular Sciences and ARC Centre of Excellence in Bioinformatics, Macquarie University, Sydney, NSW 2109, Australia and ${ }^{2}$ Department of Biochemistry, Yong Loo Lin School of Medicine, National University of Singapore, 8 Medical Drive, Singapore 117597

E-mail: Elsa Chacko - echacko@chem.mq.edu.au; Shoba Ranganathan* - shoba.ranganathan@mq.edu.au

${ }^{*}$ Corresponding author

from Asia Pacific Bioinformatics Network (APBioNet) Eighth International Conference on Bioinformatics (InCoB2009)

Singapore 7-II September 2009

Published: 3 December 2009

BMC Genomics 2009, I0(Suppl 3):SII doi: 10.1186/I47I-2164-I0-S3-SII

This article is available from: http://www.biomedcentral.com/I47I-2/64/I0/S3/SI I

(C) 2009 Chacko and Ranganathan; licensee BioMed Central Ltd.

This is an open access article distributed under the terms of the Creative Commons Attribution License (http://creativecommons.org/licenses/by/2.0), which permits unrestricted use, distribution, and reproduction in any medium, provided the original work is properly cited.

\begin{abstract}
Background: Alternative splicing (AS) is a primary mechanism of functional regulation in the human genome, with $60 \%$ to $80 \%$ of human genes being alternatively spliced. As part of the bovine genome annotation team, we have analysed 4567 bovine AS genes, compared to 16715 human and 1649 I mouse AS genes, along with Gene Ontology (GO) analysis. We also analysed the two most important events, cassette exons and intron retention in 94 human disease genes and mapped them to the bovine orthologous genes. Of the 94 human inherited disease genes, a protein domain analysis was carried out for the transcript sequences of 12 human genes that have orthologous genes and have been characterised in cow.

Results: Of the 21,755 bovine genes, 4,567 genes (21\%) are alternatively spliced, compared to $16,7 \mid 5(68 \%)$ in human and $16,49 \mid(57 \%)$ in mouse. Gene-level analysis of the orthologous set suggested that bovine genes show fewer AS events compared to human and mouse genes. A detailed examination of cassette exons across human and cow for 94 human disease genes, suggested that a majority of cassette exons in human were present and constitutive in bovine as opposed to intron retention which exhibited $50 \%$ of the exons as present and $50 \%$ as absent in cow. We observed that AS plays a major role in disease implications in human through manipulations of essential/functional protein domains. It was also evident that majority of these 12 genes had conservation of all essential domains in their bovine orthologous counterpart, for these human diseases.

Conclusion: While alternative splicing has the potential to create many mRNA isoforms from a single gene, in cow the majority of genes generate two to three isoforms, compared to six in human and four in mouse. Our analyses demonstrated that a smaller number of bovine genes show greater transcript diversity. GO definitions for bovine AS genes provided $38 \%$ more functional information than currently available in the sequence database. Our protein domain analysis helped us verify the suitability of using bovine as a model for human diseases and also recognize the contribution of AS towards the disease phenotypes.
\end{abstract}




\section{Background}

Protein diversity in eukaryotic genomes is mainly credited to alternative splicing (AS). It is a fundamental mechanism by which a single pre-mRNA can produce more than one transcript. It is also considered by many to be an important mechanism for controlling gene expression [1]. The introns in the pre-mRNA are spliced out and the exons are united in different combinations leading to a change in the primary transcript structure. This change in transcript structure can affect the encoded protein thereby disrupting its structure and also its function. The disruption in the protein structure and function brought about by AS are frequently associated with diseases [2]. Results from previous studies indicate that more than $60 \%$ of human genes are alternatively spliced [3-9].

Association of AS with many diseases such as cardiovascular, cancer and neurodegenerative disorders sheds light on the fact that it is crucial to conduct an in-depth study on AS [10]. Analyses have also shown that $15 \%$ of point mutations that cause genetic disease affect pre-mRNA splicing [10], providing a link between AS events and inherited genetic diseases.

Large scale sequencing of eukaryotic genomes and the knowledge of AS being an important player in controlling gene regulation has seen the emergence of several efforts [3-9] to create bioinformatics resources on alternative transcripts and protein isoforms [11]. Conflicting results from previous analyses aiming to compare the rate of alternative splicing between different organisms contradict AS databases who discuss genome-wide computational analysis. All vertebrates and invertebrates showed a similar rate of alternative splicing with respect to both the number of genes affected and the number of variants per gene in a large-scale expressed sequence tag (EST) analysis across distinct eukaryotes by Brett and coworkers [12]. On the contrary considerable variation in the rates of alternative splicing across organisms was reported by Lee and co-workers [5]. Understanding the phenomenon of AS is difficult as these databases do not provide sufficient information for multi-gene comparison across various species. ASAP II [5] concentrates mainly on comparative and evolutionary studies. ECGene [9] provides functional annotation for AS genes in various genomes. Alternative Splicing Transcript Database (ASTD) [3,4] does an exhaustive analysis of AS events in three species, namely human, mouse and rat. Representing the transcripts and their relation to each other has become extremely complicated due to the increasing number of transcripts for each gene. This has seen the dawn graph theory and its application to represent a gene transcript. Graph theory is a prominent concept that has been used to express transcripts and capture their relation, among many other solutions. The language of graph theory offers a mathematical abstraction for the description of biological relationships [13]. Modrek and Lee used directed acyclic graphs for EST analysis, with the genomic DNA sequence as reference [14]. Pevzner and coworkers [15] were the first to use de Bruijn graphs to depict the transcripts alone, without referring to the genomic DNA sequence, where the maximum common sub-sequences between transcripts were condensed into nodes and the variable regions connected by edges. Alternative Splicing Gallery (ASG) resource uses such an approach [7].

Our group has used directed acyclic splicing graphs, without a genomic DNA sequence as reference, with exons as nodes, interconnected by introns as edges, where the paths through the splicing graph represents the transcripts. This scheme was applied to the genomewide analysis of Drosophila melanogaster [6], leading to the DEDB data resource. Here, the first transcript served as a reference sequence to generate splicing graphs, with automatic rule-based classification of splicing events. To reduce the uncertainty in selecting the primary transcript, this methodology was further enhanced. The most conserved exons in all transcripts of a given gene were chosen to be distinct reference exons and all others were considered to be variant exons. In order to generate a splicing graph from a set of transcripts for a given gene, we thereby developed the Alternative Splicing Graph Server (ASGS) [8].

As a part of the bovine genome annotation team, we have used comparative genomics in order to associate alternative splicing patterns in human and mouse to cow [16]. Comparative genomics studies the correlation between genome structures and functions across different biological species. It aims at understanding many aspects of the evolution of modern species.

The intermediate evolutionary distance between human and bovine is 70-100 Myr [17]. The bovine model has been found to be relevant to human health research priorities such as obesity, female health and communicable diseases. Cow provides a valuable biological model in these significant areas because of the vast amount of research that has been conducted with respect to genetic and environmental interactions associated with complex, multi-genic physiological traits [18]. The Cetartiodactyl order of mammals, to which cattle and all other ruminants belong, is phylogenetically distant from the primates, and thus contains invaluable information for understanding human genome evolution [19].

In this study, we have analysed transcripts for each gene in the bovine genome. Since the bovine genome is not 
yet completely annotated we minimized any gene structure bias in the input data by carrying out comparative genome analysis on the orthologous subset of AS genes for the three species. We present here the comprehensive analysis of all bovine, human and mouse transcripts based on splicing graphs. AS events in these three genomes and their functional significance in terms of gene ontology (GO) [20] classifications were also identified. The two main AS events (cassette exons and intron retention) in the human disease genes (94) from NCBI Genes and Disease database [21] were mapped onto their respective bovine orthologous genes. A protein domain analysis on 12 human disease genes that are known to be occurring in cow was vital in providing significant insights into the protein structure/ function affects of AS.

\section{Materials and methods \\ Data}

For AS analysis, the GTF files for Bos taurus, Homo sapiens and Mus musculus were extracted from Ensembl ver. 54 [22]. Each line in the Gene Transfer Format (GTF) [23] file corresponds to the structure of the exons making up the transcripts, coding sequence, start codon and stop codon information. For our analysis, we extracted only the protein coding genes and eliminated the pseudo genes and mitochondrial genes. The unspliced transcript sequences were also obtained from Ensembl for cow to analyse the splice site motifs.

\section{Splicing graphs}

The procedure used in ASGS [8] has been adopted for compiling the graphs. The transcript information, including start and stop of each exon are compiled from the GTF file for each of the three genomes to generate the splicing graph. All transcripts are converted to the leading strand for consistency. Exons are divided into two main groups; distinct and variant. The exon that occurs in the majority of transcripts is retained as the distinct exon, with the rest classified as variant. When exons overlap, the exons with well-determined borders, occurring in most of the transcripts is considered to be distinct. If an exon is completely contained in another larger exon, these are not merged but retained as individual exons, considered variant and then entered into a list maintaining the mapping of variant exons to distinct exons [24]. Splicing graphs are then generated using these distinct and variant exons. The first line of the resultant splicing graph is composed entirely of distinct exons, followed by subsequent lines showing the locations of variable exons. The exons are connected by edges, representing introns in the set of transcripts provided. Splicing graphs were compiled for every alternatively spliced gene for the three genomes. The splicing graphs were then further analysed to identify the splicing events and patterns for orthologous genes.

\section{Detection and classification of alternative splicing events and patterns}

We have analysed nine alternative splicing events namely, cassette exons, intron retention, alternative donor sites, alternative acceptor sites, alternative transcriptional start and termination sites, alternative initiation and termination exons and mutually exclusive exons. Figure 1 defines the rules to locate each of the nine events and these rules were applied to generate the splicing graphs. This classification schema has been previously described in DEDB [6] and incorporated into ASGS [8] for the identification of the splicing events. 5 'and 3 'ends of the transcripts are usually difficult to determine experimentally due to sequencing errors which could cause anomalies in the analysis of alternative transcriptional start and termination sites [6]. The other internal AS events, however, are not affected by these sequencing errors. Two types of analyses namely gene level and event level were carried out. The percentage of total events present in each

\begin{tabular}{|c|c|c|}
\hline AS event & Splicing graph & Comments \\
\hline Cassette exon & & $\begin{array}{l}\text { A node whose start and end } \\
\text { position falls within a single } \\
\text { connection. } \\
\text { The node should have at least } \\
\text { one next and previous connection. }\end{array}$ \\
\hline $\begin{array}{l}\text { Alternative } \\
\text { transcription start } \\
\text { site }\end{array}$ & & $\begin{array}{l}\text { A node having no pervious } \\
\text { connection with unique start } \\
\text { position. }\end{array}$ \\
\hline $\begin{array}{l}\text { Alternative } \\
\text { transcription } \\
\text { termination site }\end{array}$ & & $\begin{array}{l}\text { A node having no next } \\
\text { connections with a unique end } \\
\text { position }\end{array}$ \\
\hline Intron retention & & $\begin{array}{l}\text { A node having a connection } \\
\text { whose start and end positions fall } \\
\text { within itself. }\end{array}$ \\
\hline $\begin{array}{l}\text { Mutually exclusive } \\
\text { exon }\end{array}$ & & $\begin{array}{l}\text { A node, which appears in two } \\
\text { transcriptional path }\end{array}$ \\
\hline $\begin{array}{l}\text { Alternative initiation } \\
\text { site }\end{array}$ & & $\begin{array}{l}\text { A node having no previous } \\
\text { connections with a unique end } \\
\text { position. }\end{array}$ \\
\hline $\begin{array}{l}\text { Alternative } \\
\text { termination site }\end{array}$ & & $\begin{array}{l}\text { A node having no next } \\
\text { connections with a unique start } \\
\text { position. }\end{array}$ \\
\hline $\begin{array}{l}\text { Alternative acceptor } \\
\text { site }\end{array}$ & & $\begin{array}{l}\text { A set of overlapping nodes that } \\
\text { are connected to a common } \\
\text { upstream node. } \\
\text { The set of overlapping nodes } \\
\text { should have unique start } \\
\text { positions. }\end{array}$ \\
\hline $\begin{array}{l}\text { Alternative donor } \\
\text { site }\end{array}$ & & $\begin{array}{l}\text { A set of overlapping nodes that } \\
\text { are connected to common } \\
\text { downstream node. } \\
\text { The set of overlapping nodes } \\
\text { should have unique end positions. }\end{array}$ \\
\hline
\end{tabular}

Figure I

Generation of alternative splicing (AS) events using splicing patterns. Rules were derived to detect nine alternative splicing events. Distinct exons are shown in black, while variant exons are shown in blue. 
genome for the orthologous genes is portrayed by the event level analysis. The gene level analysis calculates the percentage of all AS genes and orthologous AS genes showing each of the events for the three genomes.

Splicing graphs have been made more informative to help identify distinct and associated variant exons by visual representation of distinct (D) exons in black and variant (V) exons as blue. AS events can therefore be depicted using a minimum of four sub-graph components called splicing patterns. Figure 2 depicts the four unique sub-graphs Class I (D-D), Class II (D-V), Class III (V-D) and Class IV (V-V). The fundamental definition of transcript diversity is given by a detailed analysis of the relationship of each exon to its successor, designated as a splicing pattern.

Qualitative and quantitative analysis of exons and introns Basic statistical measures like the mean, median and standard deviation were calculated for all three genomes in order to analyse the exon and intron size conservation across the three genomes for the complete and orthologous AS gene sets. The number of exons per transcript for the three genomes was also calculated.

\section{Splice site motif analysis}

Splice site mutations are believed to cause several genetic diseases. It is therefore very important to identify variations in the splice site. The frequencies of GT-AG,

D

D

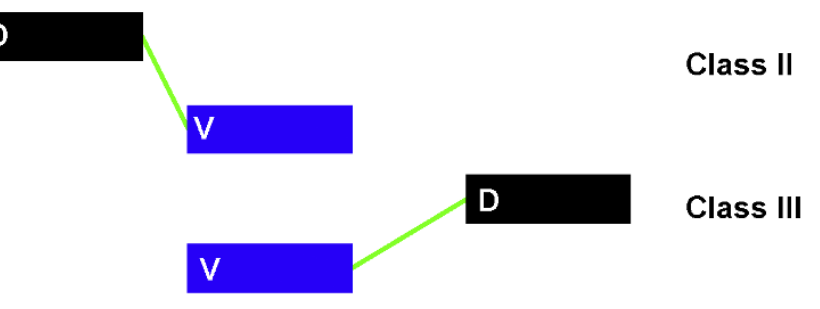

V

v

Class IV
GC-AG, AT-AC splice site motifs were computed for bovine and analysed and compared to the splice site information for human and mouse obtained from ASTD.

\section{GO annotation}

Analysis of the GO annotations was conducted for two sets of data. In the first set, the transcript sequences of orthologous bovine AS genes obtained from Ensembl were processed using ESTScan, as it can detect and extract coding regions from low quality sequences with high selectivity and sensitivity and is also able to accurately correct frame shift errors [25]. To obtain even datasets, the human and mouse transcript sequences were also processed using ESTScan. The output was then processed using another bioinformatics tool, Blast2GO [26], which we have successfully used in the annotation of expressed sequence tag sequences [27]. The BLAST results from this program were then mapped to GO terms to obtain the GO annotation. The annotation output file was then processed using a plotting tool, WEGO [28] in tool to compile the GO annotation results into category-based lists.

The second dataset was a text file comprising GO annotations for bovine AS genes orthologous to human and mouse AS genes, obtained from Ensembl using the BioMart [29] tool. The second dataset was reformatted and put through the WEGO tool to compile the GO annotation results for plotting.

\section{Mapping of human disease genes to bovine orthologous genes}

A well-annotated set of all available (94) human disease genes was extracted from NCBI Genes and Disease database [21], with the view towards analysing which of these genes were alternatively spliced in human and bovine genomes. Of these 94 genes, AS analysis was conducted on the 66 spliced genes (with more than one transcript). The two most important events, cassette exon and intron retention, were examined in detail in these 66 genes. These exons were then mapped onto the orthologous exons in bovine using CLUSTALX [30] multiple sequence alignment tool to identify the conservation of these exons and the splicing event, across the two species. Irrespective of the position of the exons in different transcripts, if two pairs of exons have a good percentage of alignment they are still considered as conserved exons, thereby implying that in the event of exon shuffling, the exon pairs are still considered conserved.

Protein domain analysis of the orthologous disease gene set We identified eight human disease genes that have bovine orthologues. The protein sequences encoded by 
the transcripts for these human and bovine genes were analyzed using Pfam [31] domain search tool to identify the effects of alternative splicing on the functional protein domains.

\section{Results and discussion}

It was observed that only $21 \%$ of bovine genes were alternatively spliced as opposed to $68 \%$ of genes in human and $57 \%$ of genes in mouse upon comparison of 4567 bovine AS genes with 16715 human AS genes and 16491 mouse AS genes. The statistics provided by ASAP II database (26\%, 53\%, 53\% for cow, mouse and human respectively) [5] compare well to these estimates of the number of AS genes in cow, mouse and human, although they appear almost twice as much as those reported by Nagasaki and group [32] (32.1\% and 23\% for human and mouse genomes, respectively). All AS genes in cow which have alternatively spliced orthologues in both human and mouse were extracted to minimize any gene structure bias and to get the bestannotated genes in cow for analysis. Such an approach has been adopted by the studies of Chen et al [33]. In order to compile the orthologous genes subset, one-toone, many-to-many, one-to-many and apparent mappings have been used. We found that 3504 genes in cow have alternatively spliced orthologues in human and mouse amounting to 3835 and 3774 genes respectively. This dataset amounted to $16 \%$ of bovine alternatively spliced genes, compared to $16 \%$ in human and $13 \%$ in mouse. Our values are consistent with those $(10 \%)$ observed by Brett et al. [12] for AS between human and other species, including mouse and cow reinstating the credibility of our approach of using orthologous AS gene subsets for multi-species comparisons and to estimate the extent of AS in cow.

Qualitative and quantitative analysis of exons and introns Compared to 8.0 and 6.5 transcripts per gene in human and mouse respectively, our results indicate that bovine AS genes are represented by 2.3 transcripts per gene on average. Overall, bovine AS genes show less transcript diversity compared to human and mouse AS genes as indicated by these numbers which are quite similar to those in the orthologous gene set as well. General statistical characteristics of the intron-exon structure of eukaryotic genomes are invaluable for understanding the structure and evolution of genes and genomes. Deutsch and Long [34] estimated that each gene comprises 5.0 exons of mean length $51 \mathrm{nt}$ separated by introns of mean length $3413 \mathrm{nt}$; and 4.4 exons of mean length $52 \mathrm{nt}$ separated by introns of mean length $1321 \mathrm{nt}$ for human and mouse genes, respectively, using available gene structure information on ten model organisms. We found that each bovine transcript comprises close to 13 exons of mean length $181 \mathrm{nt}$, separated by introns of mean length $5215 \mathrm{nt}$, while human and mouse transcripts comprise close to 8 and 7 exons, respectively, of mean length 178 and $160 \mathrm{nt}$, respectively; separated by introns averaging 5314 and 4311 nt, respectively (Table 1). While all three transcriptomes are composed of exons and introns of similar size, bovine AS genes are more fragmented than human and mouse AS genes since these numbers are again similar to those obtained for the orthologous AS gene set.

\section{Splicing graphs}

We generated a total of 4567 bovine, 16715 human and 16491 mouse splicing graphs. The transcript structure of each multi-transcript gene for all three genomes was compiled using the splicing graph approach [8]. The splicing graphs were further decomposed into component splicing patterns (as described in Materials and methods). It was noted that 2485 bovine genes are single exonic genes. It is possible to verify all the splicing events from the splicing graphs thereby suggesting that it could be utilised as an excellent visual analysis tool. One such splicing graph of $M \gamma c$ responsible for causing the disease Burkitt Lymphoma is shown in Figure 3. It can be easily seen from Figure 3 that the gene has two different transcripts.

Table I: Comparison of alternative splicing in bovine, human and mouse genomes

\begin{tabular}{|c|c|c|c|c|c|c|c|}
\hline Genome & Genes & $\begin{array}{l}\text { Genes with } \\
\text { multiples } \\
\text { transcripts }\end{array}$ & $\begin{array}{l}\% \text { of } \\
\text { alternative } \\
\text { splicing }\end{array}$ & $\begin{array}{l}\text { Transcripts per gene } \\
(\text { mean } \pm \text { sd }(\text { med }))\end{array}$ & $\begin{array}{c}\text { Exon numbers } \\
\text { per transcript } \\
(\text { mean } \pm \text { sd }(\text { med }))\end{array}$ & $\begin{array}{c}\text { Exon size (nt) } \\
(\text { mean } \pm \text { sd }(\text { med }))\end{array}$ & $\begin{array}{c}\text { Intron size (nt) } \\
(\text { mean } \pm \text { sd }(\text { med }))\end{array}$ \\
\hline Bovine & 21755 & 4567 & $21 \%$ & $2.3 \pm 1.2(3)$ & $13.4 \pm 10.5(9)$ & $181 \pm 254(126)$ & $5215 \pm 17003(1191)$ \\
\hline Human & 24573 & 16715 & $68 \%$ & $8.0 \pm 8.0(7)$ & $7.7 \pm 5.9(6)$ & $178 \pm 196(89)$ & $5314 \pm 4112(4517)$ \\
\hline Mouse & 28931 & 16491 & $57 \%$ & $6.5 \pm 6.0$ & $6.6 \pm 4.2(5)$ & $160 \pm 167(63)$ & $43 I I \pm 4003(3889)$ \\
\hline \multicolumn{8}{|c|}{ Orthologous gene set } \\
\hline Bovine & 21755 & 3504 & $16 \%$ & $2.5 \pm 1.0(3)$ & $14.4 \pm 9.8(10)$ & $162 \pm 212(123)$ & $5105 \pm 16900(1152)$ \\
\hline Human & 24573 & 3835 & $16 \%$ & $9.4 \pm 7.4(8)$ & $9.1 \pm 7.8(8)$ & $188 \pm 150(101)$ & $5210 \pm 4013(4321)$ \\
\hline Mouse & 28931 & 3774 & $13 \%$ & $7.0 \pm 6.4(6)$ & $9.0 \pm 7.2(7)$ & $145 \pm 163(103)$ & $4304 \pm 3921$ (3789) \\
\hline
\end{tabular}

Mean, standard deviation (sd) and median (med) values have been computed for columns 5-8. 
Splicing Pattern

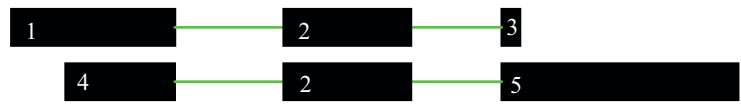

Splicing Graph

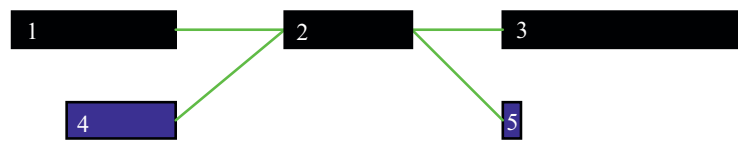

Figure 3

Splicing graph for the human disease gene Myc (Burkitt Lymphoma). The splicing graph represents the gene in a very simple and easily understandable format.

\section{Alternative splicing events and patterns}

The nine AS events discussed above have been identified in the orthologous set for bovine genome and are compared to those in human and mouse. Equation 1 was used to calculate the \% of genes showing each AS event in each of the three genomes for the gene level analysis.

$$
\begin{aligned}
\text { Percentage of genes }= & (\text { No. of genes showing each event } / \\
& \text { Sum of all the genes that exhibit AS events }) \times 100
\end{aligned}
$$

The first four AS event categories in Figure. 4, refer to splicing events at the ends of a gene, while the remaining five represent internal events. The results of our gene level analysis highlight that most of the genes showed external events. As suggested earlier the high percentage for transcriptional start and termination sites events could be the result of sequencing errors. We observed

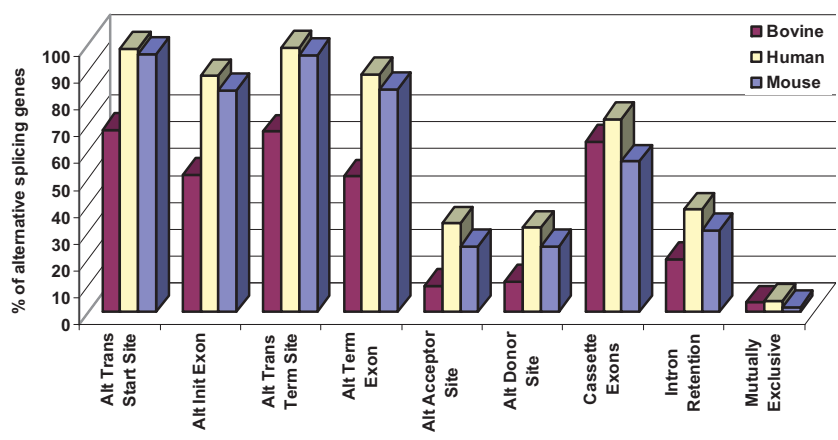

Figure 4

Distribution of AS events - gene level analysis for bovine, human and mouse orthologous AS genes. Nine events, described in Figure I, were used to classify the observed AS phenomena based on the number of genes displaying these events, as shown in Table 2. that majority of the genes in cow (59\%-64\%) have cassette exons, with 19\%-20\% of the genes having intron retention. Very few genes exhibited mutually exclusive exons (3\%-4\%). Figure 4 clearly shows that fewer bovine genes exhibit AS events than that of those in human and mouse. The values for both the datasets of all three genomes is tabulated in Table 2.

It should be noted that each AS gene contains several events. The distribution of each event compared to the total number of AS events observed in the orthologous set of the three genomes represent the event level analysis as shown in Equation 2. (Table 3, Figure 5).

Percentage of events $=($ No. of times an event occurs $)$

Sum of the occurences of all the events $) \times 100$

Considerable conservation was observed in each of the nine AS events for the three species. Our analysis proves that exon skipping or cassette exon is the most prevalent internal AS event in the orthologous genes of all three species, comprising $28 \%, 26 \%$ and $16 \%$ of all AS events in bovine, human and mouse, respectively. On the other hand, intron retention and mutually exclusive exons were the least favoured AS events. Intron retention accounted for only $3 \%$ of bovine AS events, compared to $3 \%$ in human and $2 \%$ in mouse. Haussler and coworkers [35] estimated 38\% exon skipping and 3\% intron retention in human, which are very similar to our values. ASD $[3,4]$ reports $52 \%$ cassette exons and $17 \%$ intron retention, which differ considerably from our calculations. This could however be due to the fact that ASD has used the entire human genome for their calculations whereas we have only utilized orthologous AS genes for our analysis.

Overall, from the two sets of analyses, fewer bovine genes show equivalent $\%$ of AS events compared to human and mouse, which implies that these orthologous AS genes in cow show high variation between the transcripts structure, despite low number of actually different transcripts as opposed to human and mouse genes.

The splicing pattern analysis was done for the orthologous AS genes by calculating the percentage of the four classes in the splicing pattern to determine the exact nature of the transcript diversity. Among all the patterns described above we observe that Class I (DistinctDistinct) patterns have the highest occurrence (70\%) (Table 4 and Figure 6). Class IV (Variable-Variable) is over-represented $(13 \%)$ in bovine genes compared to human $(5 \%)$ and mouse $(6 \%)$. The diversity in bovine AS genes is thus predominantly composed of edges linking two variable exons, as opposed to human and 
Table 2: Statistics of alternative splicing events for all AS genes and the orthologous AS gene subset (gene level analysis)

\begin{tabular}{|c|c|c|c|c|c|c|}
\hline $\begin{array}{l}\text { Type of alternative } \\
\text { splicing event }\end{array}$ & $\begin{array}{c}\text { Bovine } \\
\text { (Complete set) }\end{array}$ & $\begin{array}{c}\text { Bovine } \\
\text { (Orthologous } \\
\text { set) }\end{array}$ & $\begin{array}{c}\text { Human } \\
\text { (Complete set) }\end{array}$ & $\begin{array}{c}\text { Human } \\
\text { (Orthologous } \\
\text { set) }\end{array}$ & $\begin{array}{c}\text { Mouse } \\
\text { (Complete set) }\end{array}$ & $\begin{array}{c}\text { Mouse } \\
\text { (Orthologous } \\
\text { set) }\end{array}$ \\
\hline Transcriptional Start Site & $3136(69 \%)$ & $2380(68 \%)$ & $16180(97 \%)$ & $377 \mid(98 \%)$ & 15357 (93\%) & $3629(96 \%)$ \\
\hline Alternative Initiation Exons & $2476(54 \%)$ & 1795 (51\%) & 13605 (81\%) & 3379 (88\%) & $12142(74 \%)$ & $3117(82 \%)$ \\
\hline Transcriptional Termination Site & 3787 (83\%) & $2358(67 \%)$ & $16558(99 \%)$ & 3778 (98\%) & 16111 (98\%) & 3621 (96\%) \\
\hline Alternative Termination Exons & $3306(72 \%)$ & $1774(51 \%)$ & $15060(90 \%)$ & $340 ।(89 \%)$ & 14276 (86\%) & $3136(83 \%)$ \\
\hline Alternative Acceptor & 404 (9\%) & $344(10 \%)$ & $4580(27 \%)$ & $1270(33 \%)$ & $3265(20 \%)$ & $926(25 \%)$ \\
\hline Alternative Donor & 454 (10\%) & $394(11 \%)$ & $4517(27 \%)$ & $1209(32 \%)$ & $3297(20 \%)$ & $925(25 \%)$ \\
\hline Cassette Exons & $2706(59 \%)$ & $2227(64 \%)$ & $10135(60 \%)$ & $2757(72 \%)$ & $7081(43 \%)$ & $2120(56 \%)$ \\
\hline Intron Retention & 875 (19\%) & $695(20 \%)$ & $5564(33 \%)$ & | 468 (38\%) & $4348(26 \%)$ & 1153 (31\%) \\
\hline Mutually Exclusive & $148(3 \%)$ & $124(4 \%)$ & $382(3 \%)$ & $158(4 \%)$ & $158(1 \%)$ & $70(2 \%)$ \\
\hline
\end{tabular}

Data on nine AS events described in Table 4 have been compiled.

Table 3: Statistics of alternative splicing events for the orthologous gene subset (event level analysis)

\begin{tabular}{lccc}
\hline $\begin{array}{l}\text { Type of alternative } \\
\text { splicing event }\end{array}$ & Bovine & Human & Mouse \\
\hline $\begin{array}{l}\text { Transcriptional Start Site } \\
\text { Alternative Initiation Exons }\end{array}$ & $5177(17 \%)$ & $28311(19 \%)$ & $21556(22 \%)$ \\
$\begin{array}{l}\text { Transcriptional Termination } \\
\text { Site }\end{array}$ & $5126(13 \%)$ & $17177(11 \%)$ & $14030(14 \%)$ \\
Alternative Termination & $3851(13 \%)$ & $17243(11 \%)$ & $14119(14 \%)$ \\
Exons & & & \\
Alternative Acceptor & $822(3 \%)$ & $7790(5 \%)$ & $3820(4 \%)$ \\
Alternative Donor & $934(3 \%)$ & $7582(2 \%)$ & $3964(4 \%)$ \\
Cassette Exons & $8337(28 \%)$ & $39368(26 \%)$ & $15943(16 \%)$ \\
Intron Retention & $853(3 \%)$ & $3694(3 \%)$ & $2307(2 \%)$ \\
Mutually Exclusive & $254(1 \%)$ & $344(0.2 \%)$ & $155(0.2 \%)$ \\
Total events & 29277 & 149773 & 97428 \\
\hline
\end{tabular}

Data on nine AS events described in Table 4 have been compiled.

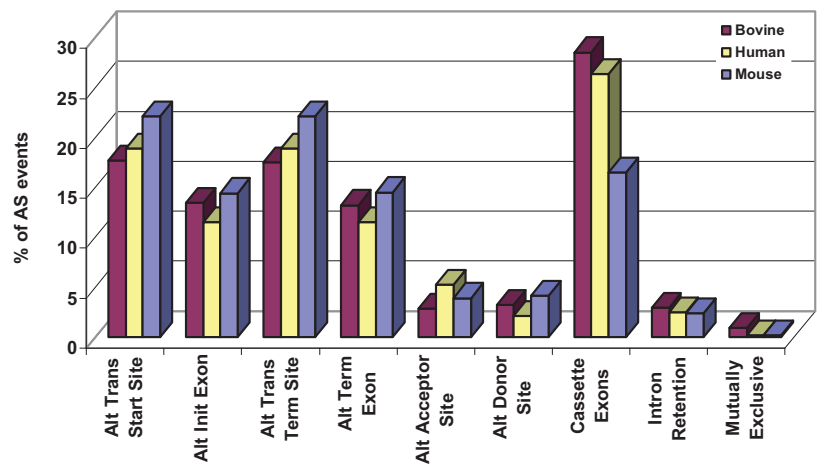

Figure 5

Distribution of alternative splicing events-event level analysis for bovine, human and mouse orthologous AS genes. Event level analysis of each of the nine events, described in Figure I and based on the data in Table 3.
Table 4: Alternative splicing class distribution based on splicing patterns for orthologous bovine, human and mouse AS genes

\begin{tabular}{lcccc}
\hline Genome & Class I & Class II & Class III & Class IV \\
\hline Bovine & $73588(70 \%)$ & $8776(8 \%)$ & $8843(8 \%)$ & $13754(13 \%)$ \\
Human & $223022(75 \%)$ & $28725(10 \%)$ & $28759(10 \%)$ & $14299(5 \%)$ \\
Mouse & $149036(73 \%)$ & $21281(10 \%)$ & $21284(10 \%)$ & $11298(6 \%)$ \\
\hline
\end{tabular}

Table 5: Splice site motif analysis for bovine, human and mouse AS genes

\begin{tabular}{lccc} 
Splice site motifs & Bovine & Human (ASTD) & Mouse (ASTD) \\
\hline GT-AG & $99 \%$ & $98 \%$ & $99 \%$ \\
GC-AG & $0.93 \%$ & $2 \%$ & $1 \%$ \\
AT-AC & $0.07 \%$ & $0 \%$ & $0 \%$ \\
\hline
\end{tabular}

mouse AS genes, where the transcript diversity is predominantly composed of edges linking a distinct exon with a variable one or vice versa.

\section{Splice site motif analysis}

The splice site motif analysis yielded consistent values in the three genomes. $99 \%$ of the splice site motifs in bovine AS genes were found to be GT-AG (Table 5). The data for the orthologous AS gene set is very similar (data not shown).

\section{GO analysis of orthologous gene sets}

Gene Ontology (GO) analysis was carried out for all three organisms on the orthologous AS gene set where the GO categories were selected based on the work done by Chen et al [33]. The transcript sequences for the orthologous AS genes of human, mouse and bovine were analyzed. It was observed that the overall GO categories for all the three species were very similar (Table 6 and Figure 7). In the area of molecular function, the highest functionality was observed for "binding" in all three species. In terms of biological 


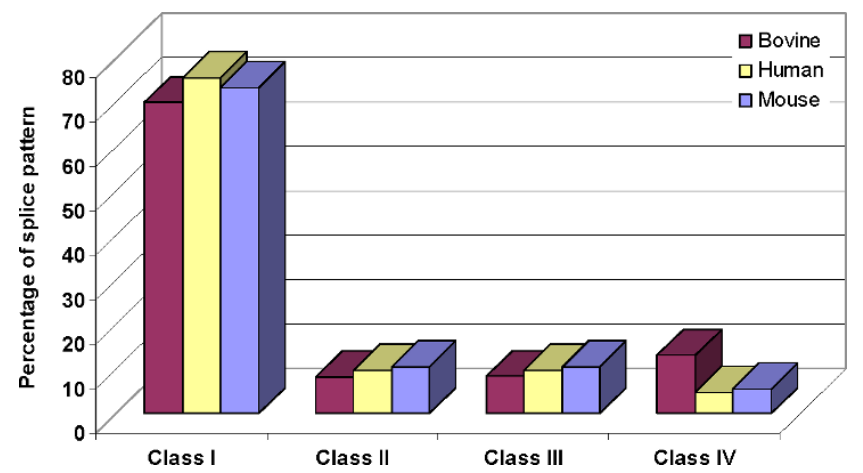

Figure 6

Splicing pattern distribution in the orthologous bovine, human and mouse alternatively spliced genes. Statistics on four component splicing patterns have been complied, with the transcript diversity index defined as the fraction of all patterns involving variant exons. process, "cellular processes" was the preferred category, while for cellular component, "cell part" was most popular. This high similarity in functionality could reflect the common lineage of bovine, human and mouse, as mammalian.

However, a similar plot was also created for the bovine genome, using a different set of annotations, where the entire GO details were obtained from Ensembl using the BioMart tool [28]. This analysis showed considerably low percentage for bovine as opposed to the previous plot. This, we believe can be a result of low level of annotation available for bovine genes. In this plot, a considerable drop in functionality was noticed across all the areas for bovine genome (Table 6 and Figure 7). Therefore, we were able to identify $38 \%$ more functional information in terms of GO annotations than currently available in Ensembl for bovine genes.

Table 6: Gene ontology (GO) annotation summary for the orthologous AS gene set

\begin{tabular}{|c|c|c|c|c|}
\hline A. Molecular function & $\begin{array}{l}\text { \%Bovine } \\
\text { (Ensembl) }\end{array}$ & $\begin{array}{l}\% \text { Bovine } \\
\text { genes }\end{array}$ & $\begin{array}{l}\% \text { Human } \\
\text { genes }\end{array}$ & $\begin{array}{c}\% \text { Mouse } \\
\text { Genes }\end{array}$ \\
\hline Binding & 33.5 & 69.86 & 70.43 & 69.53 \\
\hline Catalytic activity & 14.9 & 33.22 & 32.67 & 32.8 \\
\hline Molecular transducer activity & 4.42 & 11.07 & 11.58 & 11.47 \\
\hline Transporter activity & 3.54 & 9.56 & 9.41 & 9.33 \\
\hline Transcription regulator activity & 2.03 & 8.33 & 8.16 & 8.35 \\
\hline Enzyme regulator activity & 2.8 & 6.68 & 6.39 & 6.44 \\
\hline Structural molecule activity & 1.57 & 4.11 & 4.28 & 4.32 \\
\hline Other & 0.94 & 3.08 & 3.34 & 3.07 \\
\hline B. Biological process & $\begin{array}{l}\text { \% Bovine } \\
\text { (Ensembl) }\end{array}$ & $\begin{array}{c}\% \text { Bovine } \\
\text { genes }\end{array}$ & $\begin{array}{l}\% \text { Human } \\
\text { genes }\end{array}$ & $\begin{array}{c}\text { \% Mouse } \\
\text { Genes }\end{array}$ \\
\hline Cellular process & 30.62 & 67.78 & 67.77 & 67.97 \\
\hline metabolic process & 20.58 & 47.26 & 47.67 & 47.72 \\
\hline Biological regulation & 12.99 & 31.74 & 31.89 & 31.96 \\
\hline Developmental process & 10.9 & 26.08 & 26.44 & 26.79 \\
\hline Multicellular organismal process & 10.53 & 24.2 & 24.35 & 24.75 \\
\hline Localization & 9.67 & 23.43 & 22.69 & 23.21 \\
\hline Establishment of localization & 8.08 & 20.12 & 19.74 & 19.82 \\
\hline Response to stimulus & 6.22 & 15.33 & 16.01 & 16.93 \\
\hline Immune system process & 2.14 & 5.25 & 5.84 & 5.88 \\
\hline Biological adhesion & 2.63 & 5.37 & 5.35 & 5.59 \\
\hline Reproduction & 1.51 & 3.82 & 3.96 & 4.03 \\
\hline Other & 3.14 & 7.85 & 7.46 & 8.29 \\
\hline C. Cellular component & $\begin{array}{l}\text { \%Bovine } \\
\text { (Ensembl) }\end{array}$ & $\begin{array}{l}\% \text { Bovine } \\
\text { genes }\end{array}$ & $\begin{array}{l}\% \text { Human } \\
\text { genes }\end{array}$ & $\begin{array}{c}\text { \% Mouse } \\
\text { Genes }\end{array}$ \\
\hline Cell & 32.65 & 74.89 & 75.05 & 74.3 \\
\hline Cell part & 32.65 & 74.89 & 75.05 & 74.3 \\
\hline Organelle & $|8.2|$ & 44.12 & 43.75 & 44.01 \\
\hline Organelle part & 7.31 & 17.98 & 17.55 & 17.1 \\
\hline Macromolecular complex & 5.88 & 15.95 & 15.33 & 15.55 \\
\hline Extracellular region & 3.37 & 11.84 & 11.45 & 14.38 \\
\hline Extracellular region part & 2.28 & 10.45 & 10.09 & 12.35 \\
\hline Membrane-enclosed lumen & 1.86 & 5.76 & 5.63 & 5.88 \\
\hline Others & 4.17 & 10.25 & 12.7 & 10.2 \\
\hline
\end{tabular}



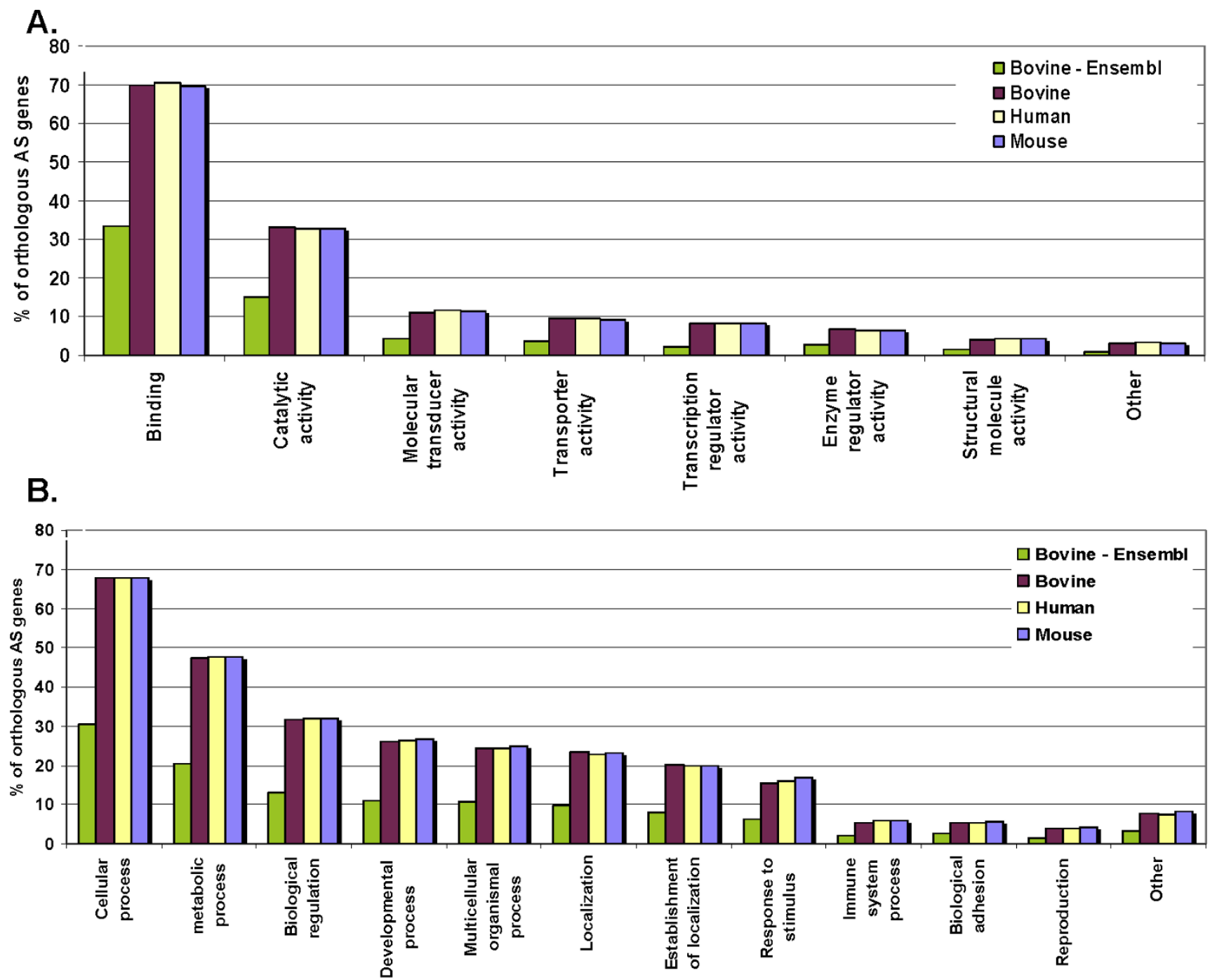

C.

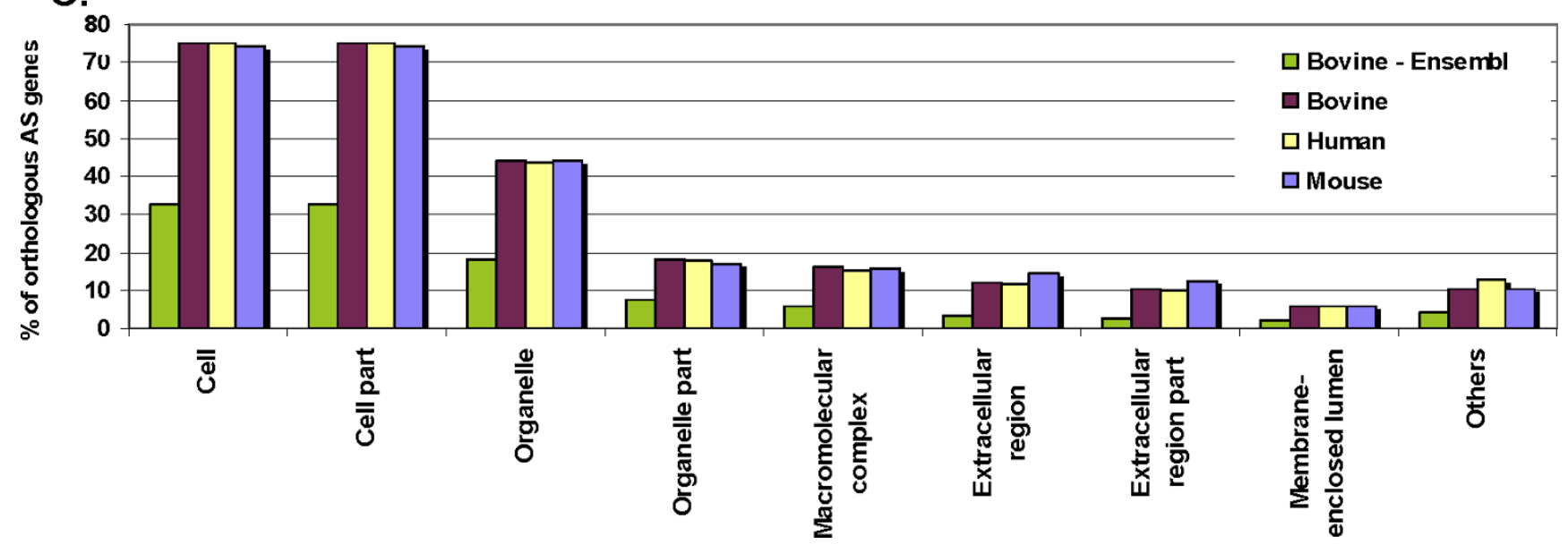

Figure 7

Occurrence of gene ontology (GO) terms in bovine, human and mouse for the orthologous AS gene subset. GO terms have been categorized on the basis of A. molecular function, B. biological process and C. cellular component. 


\section{Mapping of human disease genes to bovine orthologous} genes

The use of farm animals like cattle, pigs, sheep, goats, horses and chickens as research models has won many Nobel Prizes for researchers worldwide [36]. Various new opportunities in areas of biomedical research have been created by the application of the tools for genetic manipulation and genomic sequencing in farm animals [16]. This provides valuable insights into gene function and genetic and environmental influences on animal production and human diseases [36]. Because of the size and relatively long intervals between generations, domestic species are widely used to unravel the mechanisms involved in programming the development of an embryo and fetus, resulting in adult onset of diseases [37,38]. Rogers et al. [39] have identified that the CFTR gene knockout model of pig better mimics human pathology than mouse models as they fail to develop the hallmark pancreatic, lung and intestinal obstructions that occur in humans. Reynolds et al. [40] note that surgery, blood sampling, tissue recovery, serial biopsies, instrumentations, whole organ manipulations and many other biomedical applications are more easily achieved in animals larger than a mouse, suggesting that size does matter when it comes to animal models. Hence mapping human disease genes to bovine orthologous genes is an excellent mode for carrying out analytical work and verifying the suitability of cow as a model organism.

Out of the 94 human disease genes that were collected, we observed splicing in 66 cases, (70.21\%). Mapping these 66 spliced human genes onto orthologous bovine genes suggested that only 17 of the orthologous bovine genes were spliced (18.09\%). Cassette exons occur in 38 of human disease genes (120 cassette exons, Table 7)

Table 7: Human disease genes: Conservation of cassette exons in bovine orthologous genes

Number of cassette exons in 38 AS human disease genes

Exons present and constitutive in bovine orthologous gene

Exons present and regulated in bovine orthologous gene 7

Exons absent in bovine orthologous gene and 14 orthologous bovine genes. At the exon level, we observed that 97 of 120 human exons (Table 7) were conserved in bovine, indicating a high level of conservation in this dataset across both the species. Previously, for a larger dataset [16], it was reported that majority of genes with cassette exons in human were present and regulated in cattle. However, at the gene level, for the current dataset, we have observed that only 3 genes with cassette exons in human (Table 8) were present and regulated in bovine.

We also carried out a detailed survey of the 94 human disease genes to identify intron retention events. We noted intron retention in nine human genes out of which, in five genes IR was present and constitutive in bovine (> 50\%; Table 9). It has been indicated before that the expression of intron-containing sequences occur in a variety of diseases [41].

\section{Protein domain analysis of the orthologous disease gene set} For the eight human disease genes that have orthologous genes in the bovine genome, (three genes with CE and five genes with IR), protein domain analysis revealed that AS affects the structure and function of the proteins encoded by the various transcripts from these genes. It was evident that due to AS, the majority of the transcripts either lacked the complete functional domain or lacked an essential component/segment of the functional domain. This suggests that AS is a major machanism that could render these proteins non-functional, besides perturbing the structure or fold of the protein.

For the set of the bovine orthologous genes, only two of eight genes appear to be spliced, resulting in probable structure and function disruption. These genes are responsible for spinal muscular atrophy and colon cancer, with the former noted as a disease caused by AS [1]. Further investigation revealed that four of these eight genes had all the domains from their human counterparts conserved. This implies that $4 / 8$ orthologous bovine genes (including the two AS genes) had essential segments or complete functional domains missing, due to AS.

Table 8: Human disease genes: Cassette exons present and regulated in bovine orthologous genes

\begin{tabular}{|c|c|c|c|c|c|}
\hline Disease & $\begin{array}{l}\text { Gene } \\
\text { name }\end{array}$ & $\begin{array}{l}\text { Ensembl human } \\
\text { transcript ID }\end{array}$ & $\begin{array}{l}\text { Cassette exon position } \\
\text { in human transcript }\end{array}$ & $\begin{array}{l}\text { Ensembl bovine } \\
\text { transcript ID }\end{array}$ & $\begin{array}{l}\text { Cassette exon position in } \\
\text { bovine orthologous transcript }\end{array}$ \\
\hline Colon Cancer & MLHI & ENST0000023I790 & $\begin{array}{l}\text { Exon } 9 \\
\text { Exon } 10\end{array}$ & ENSBTAT00000022288 & $\begin{array}{l}\text { Exon9 } \\
\text { Exon } 10\end{array}$ \\
\hline Spinal muscular atrophy & SMNI & ENSG00000I72062 & $\begin{array}{l}\text { Exon6 } \\
\text { Exon5 } \\
\text { Exon32 }\end{array}$ & ENSBTAT00000007547 & $\begin{array}{l}\text { Exon6 } \\
\text { Exon5 } \\
\text { Exon32 }\end{array}$ \\
\hline Tangier disease & $\mathrm{ABCl}$ & ENST0000034I579 & $\begin{array}{l}\text { Exon2 } \\
\text { Exon } 10\end{array}$ & ENSBTAT00000027538 & $\begin{array}{l}\text { Exon2 } \\
\text { Exon } 10\end{array}$ \\
\hline
\end{tabular}


Table 9: Human disease genes: Intron retention present and constitutive in bovine orthologous genes

\begin{tabular}{|c|c|c|c|c|c|}
\hline Diseases & $\begin{array}{l}\text { Gene } \\
\text { Name }\end{array}$ & Transcript ID & Intron Ret & Transcript ID & Conserved exon in bovine \\
\hline Glaucoma & GLCIA & ENST00000037502 & Exon I & ENSBTAT00000027III & Exon I \\
\hline Spinocerebellar ataxia & SCAI & ENST00000244769 & Exon9 & ENSBTAT00000044692 & Exon3 \\
\hline \multirow[t]{2}{*}{ Polycystic kidney disease } & PKDI & ENST00000262304 & Exon 23 & ENSBTAT00000027480 & Exon 23 \\
\hline & & & Exon 15 & & Exon 15 \\
\hline Autoimmune polyglandular syndrome & APSI & ENST0000029/582 & Exon 10 & ENSBTAT0000003 | 852 & Exon 10 \\
\hline Wilson's disease & ATP7B & ENST00000242839 & Exon2 & ENSBTAT000000I3674 & Exon I \\
\hline
\end{tabular}

Wilson's disease is another disease that has been characterised in cow (OMIA). We observe that the human gene known to be responsible for this disease has a retained intron in one of its transcripts, which is orthologous to the only transcript available in the corresponding bovine gene. Thus, the cow would be most suitable as a model organism for this human disease.

\section{Conclusion}

This is the first comprehensive study of the bovine transcriptome, with $21 \%$ of bovine genes exhibiting alternative splicing, compared to $68 \%$ and $57 \%$ in human and mouse, respectively. Our analyses show that bovine AS genes are composed of fewer transcripts but many more exons than human and mouse AS genes, although comprising exons and introns of comparable extents. Nine different splicing events were compared among cow, human and mouse genomes. Compared to their human and mouse counterparts many more bovine AS genes show intron retention. The most common AS event was found to be exon skipping and the least common events were intron retention and mutually exclusive exons. With predominantly introns linking two variable exons, as opposed to human and mouse genes fewer AS bovine genes show high transcript variability.

$38 \%$ more functional information than currently available in Ensembl was identified with our approach which helped us collate the GO annotations for bovine AS genes. The orthologous bovine AS genes are functionally very similar to human and mouse genes as suggested by GO annotations.

From the results of our protein domain analysis it is evident that AS plays a major role in disease implications in both human and cow, and is suitable as a model for investigating spinal muscular atrophy, colon cancer, tangier disease, glaucoma, spinocerebellar ataxia, polycystic kidney disease, autoimmune poly grandular syndrome and wilson's disease. Our results provide a window of opportunity for more in-depth analysis over a larger dataset, where the cow can serve as a model organism for many more human diseases.

\section{Competing interests}

The authors declare that they have no competing interests.

\section{Authors'contributions}

SR conceived the alternative splicing analysis concept for the bovine genome. EC obtained the data and carried out the analysis. EC and SR wrote the paper. All authors approved the manuscript and declare that there is no conflict of interest.

\section{Note}

Other papers from the meeting have been published as part of BMC Bioinformatics Volume 10 Supplement 15, 2009: Eighth International Conference on Bioinformatics (InCoB2009): Bioinformatics, available online at http://www.biomedcentral.com/1471-2105/10? issue $=\mathrm{S} 15$.

\section{Acknowledgements}

EC is grateful to the Macquarie University for the award of the MQ Research Excellence Scholarship (MQRES). Open access publication changes are borne by Macquarie University.

This article has been published as part of BMC Genomics Volume 10 Supplement 3, 2009: Eighth International Conference on Bioinformatics (InCoB2009): Computational Biology. The full contents of the supplement are available online at http://www.biomedcentral.com//47/-2/64//0? issue $=\mathrm{S} 3$.

\section{References}

I. Caceres JF and Komblihtt AR: Alternative Splicing: multiple control mechanisms and involvement in human disease. Trends in Genetics 2002, 18:186-193.

2. Tazi J, Bakkour N and Stamm S: Alternative splicing and disease. Biochimica et Biophysica Acta 2009, 14-26.

3. Thanaraj TA, Stamm S, Clark F, Riethoven JJ, Le TV and Muilu J: ASD: the Alternative Splicing Database. Nucleic Acids Res 2004, 32(Database issue):D64-D69.

4. Stamm S, Riethoven JJ, Le Texier V, Gopalakrishnan C, Kumanduri V, Tang Y, Barbosa-Morais NL and Thanaraj TA: ASD: a bioinformatics resource on alternative splicing. Nucleic Acids Res 2006, 34(Database issue):D46-D55.

5. Kim N, Alekseyenko AV, Roy M and Lee C: The ASAP II database: analysis and comparative genomics of alternative splicing in 15 animal species. Nucleic Acids Res 2007, 35: D93-D98.

6. Lee BTK, Tan TW and Ranganathan S: DEDB: a database of Drosophila melanogaster exons in splicing graph form. $B M C$ Bioinformatics 2004, 5:189. 
7. Leipzig J, Pevzner $P$ and Heber S: The Alternative Splicing Gallery (ASG): bridging the gap between genome and transcriptome. Nucleic Acids Res 2004, 32:3977-3983.

8. Bollina D, Lee BTK, Tan TW and Ranganathan S: ASGS: an alternative splicing graph web service. Nucleic Acids Res 2006, 34:W444-W447.

9. Lee Y, Lee Y, Kim B, Shin Y, Nam S, Kim P, Kim N, Chung WH, Kim J and Lee S: ECgene: an alternative splicing database update. Nucleic Acids Res 2006, 35:D99-DI03.

10. Krawczak M, Reiss J and Cooper DN: The mutational spectrum of single base-pair substitutions in mRNA splice junctions of human genes: causes and consequences. Hum Genet 1992, 90 (I-2):4 I-54

II. Lee C and Wang Q: Bioinformatics analysis of alternative splicing. Brief Bioinform 2005, 6:23-33.

12. Brett D, Pospisil H, Valcarcel J, Reich J and Bork P: Alternative splicing and genome complexity. Nature Genet 200I, 30:29-30.

13. Huber W, Carey V], Long L, Falcon S and Gentleman R: Graphs in molecular biology. BMC Bioinformatics 2007, 8(Suppl 6):S8.

14. Modrek $B$ and Lee C: A genomic view of alternative splicing. Nature Genet 2002, 30:13-19.

15. Heber S, Alekseyev M, Sze SH, Tang H and Pevzner PA: Splicing graphs and EST assembly problem. Bioinformatics 2002, I8: SI8I-SI88.

16. The Bovine Genome Sequencing Consortium, Elsik CG, Tellam RL, Worley KC, Gibbs RA, Muzny DM, Weinstock GM, Adelson DL, Eichler EE, Elnitski L, Guigó R, Hamernik DL, Kappes SM, Lewin HA Lynn DJ, Nicholas FW, Reymond A, Rijnkels M, Skow LC. Zdobnov EM, Schook L, Womack J, Alioto T, Antonarakis SE, Astashyn A, Chapple CE, Chen HC, Chrast J, Câmara F, Ermolaeva O, Henrichsen CN, Hlavina W, Kapustin Y, Kiryutin B, Kitts P, Kokocinski F, Landrum M, Maglott D, Pruitt K, Sapojnikov V, Searle SM, Solovyev V, Souvorov A, Ucla C, Wyss C, Anzola JM, Gerlach D, Elhaik E, Graur D, Reese JT, Edgar RC, McEwan JC, Payne GM, Raison JM, Junier T, Kriventseva EV, Eyras E, Plass M, Donthu R, Larkin DM, Reecy J, Yang MQ, Chen L, Cheng Z, ChitkoMcKown CG, Liu GE, Matukumalli LK, Song J, Zhu B, Bradley DG Brinkman FS, Lau LP, Whiteside MD, Walker A, Wheeler TT, Casey T, German JB, Lemay DG, Magbool NJ, Molenaar AJ, Seo S, Stothard P, Baldwin CL, Baxter R, Brinkmeyer-Langford CL, Brown WC, Childers CP, Connelley T, Ellis SA, Fritz K, Glass EJ Herzig CT, livanainen A, Lahmers KK, Bennett AK, Dickens CM, Gilbert JG, Hagen DE, Salih H, Aerts J, Caetano AR, Dalrymple B, Garcia JF, Gill CA, Hiendleder SG, Memili E, Spurlock D, Williams JL, Alexander L, Brownstein MJ, Guan L, Holt RA, Jones SJ, Marra MA Moore R, Moore SS, Roberts A Taniguchi M, Waterman RC, Chacko J, Chandrabose MM, Cree A, Dao MD, Dinh HH, Gabisi RA Hines S, Hume J, Jhangiani SN, Joshi V, Kovar CL, Lewis LR, Liu YS, Lopez J, Morgan MB, Nguyen NB, Okwuonu GO, Ruiz S], Santibanez J, Wright RA, Buhay C, Ding Y, Dugan-Rocha S, Herdandez J, Holder M, Sabo A, Egan A, Goodell J, WilczekBoney K, Fowler GR, Hitchens ME, Lozado RJ, Moen C, Steffen D Warren JT, Zhang J Chiu R, Schein JE, Durbin KJ, Havlak $P$, Jiang $H$, Liu Y, Qin X, Ren Y, Shen Y, Song H, Bell SN, Davis C, Johnson AJ Lee S, Nazareth LV, Patel BM, Pu LL, Vattathil S, Williams RL Jr, Curry S, Hamilton C, Sodergren E, Wheeler DA, Barris W, Bennett GL, Eggen A, Green RD, Harhay GP, Hobbs M, Jann O Keele JW, Kent MP, Lien S, McKay SD, McWilliam S, Ratnakumar A, Schnabel RD, Smith T, Snelling WM, Sonstegard TS, Stone RT, Sugimoto $Y$, Takasuga A, Taylor JF, Van Tassell CP, Macneil MD, Abatepaulo AR, Abbey CA, Ahola V, Almeida IG, Amadio AF, Anatriello E, Bahadue SM, Biase FH, Boldt CR, Carroll JA, Carvalho WA, Cervelatti EP, Chacko E, Chapin JE, Cheng Y Choi J, Colley AJ, de Campos TA, De Donato M, Santos IK, de Oliveira CJ, Deobald H, Devinoy E, Donohue KE, Dovc $P$, Eberlein A, Fitzsimmons C], Franzin AM, Garcia GR, Genini S, Gladney C], Grant JR, Greaser ML, Green JA, Hadsell DL, Hakimov HA, Halgren R, Harrow JL, Hart EA, Hastings $N$ Hernandez M, Hu ZL, Ingham A, Iso-Touru T, Jamis C, Jensen K, Kapetis D, Kerr T, Khalil SS, Khatib H, Kolbehdari D, Kumar CG Kumar D, Leach R, Lee JC, Li C, Logan KM, Malinverni R, Marques E, Martin WF, Martins NF, Maruyama SR, Mazza R, McLean KL, Medrano JF, Moreno BT, Moré DD, Muntean CT, Nandakumar HP, Nogueira MF, Olsaker I, Pant SD, Panzitta F, Pastor RC, Poli MA, Poslusny N, Rachagani S, Ranganathan S, Razpet A, Riggs PK, Rincon G, Rodriguez-Osorio N, Rodriguez-Zas SL, Romero NE, Rosenwald A, Sando L, Schmutz SM, Shen L, Sherman L, Southey BR, Lutzow YS, Sweedler JV, Tammen I, Telugu BP, Urbanski JM, Utsunomiya YT, Verschoor CP, Waardenberg AJ, Wang Z, Ward R, Weikard R, Welsh TH Jr, White SN, Wilming LG, Wunderlich KR,
Yang J and Zhao FQ: The Genome Sequence of Taurine Cattle: A Window to Ruminant Biology and Evolution. Science 324:522-528.

17. Miziara I MN, Riggs PK and Amaral MEJ: Comparative analysis of noncoding sequences of orthologous bovine and human gene pairs. Genetics and Molecular Research 2004, 3:465-473.

18. Gibbs R and Weinstock G: Bovine Genome Sequencing Initiative - Cattle-izing the Human Genome. http://www. genome.gov/Pages/Research/Sequencing/SeqProposals/BovineSEQ. pdf, accessed on 15/05/2009.

19. Lewin HA: It's a Bull's Market. Science 2009, 324:478-479.

20. Ashburner M, Ball CA, Blake JA, Botstein D, Butler H, Cherry JM, Davis AP, Dolinski K, Dwight SS, Eppig JT, Harris MA, Hill DP, IsselTarver L, Kasarskis A, Lewis S, Matese JC, Richardson JE, Ringwald M, Rubin GM and Sherlock G: Gene ontology: tool for the unification of biology. The Gene Ontology Consortium. Nat Genet 2000, 25:25-29.

21. NCBI Genes and Disease database. http://www.ncbi.nlm.nih gov/books/bv.fcgi?rid=gnd, accessed on 6/5/2009.

22. Hubbard TJ, Aken BL, Beal K, Ballester B, Caccamo M, Chen $Y$, Clarke L, Coates G, Cunningham F, Cutts T, Down T, Dyer SC, Fitzgerald S, Fernandez-Banet J, Graf S, Haider S, Hammond $M$, Herrero J, Holland R, Howe K, Howe K, Johnson N, Kahari A, Keefe D, Kokocinski F, Kulesha E, Lawson D, Longden I, Melsopp C, Megy K, Meidl P, Ouverdin B, Parker A, Prlic A, Rice S, Rios D, Schuster M, Sealy I, Severin J, Slater G, Smedley D, Spudich G, Trevanion S, Vilella A, Vogel J, White S, Wood M, Cox T, Curwen V, Durbin R, Fernandez-Suarez XM, Flicek P, Kasprzyk A, Proctor G, Searle S, Smith J, Ureta-Vidal A and Birney E: Ensembl 2007. Nucleic Acids Res 2007, 35:D610-D617.

23. GTF: an Exchange Format for Feature Description. http:// www.sanger.ac.uk/Software/formats/GFF/, accessed on $08 / 09 / 2008$.

24. Chacko E and Ranganathan S: Comprehensive splicing graph analysis of alternative splicing patterns in chicken, compared to human and mouse. BMC Genomics 2009, I0(SuppI I): S5.

25. Iseli C, Jongeneel CV and Bucher P: ESTScan: a program for detecting, evaluating, and reconstructing potential coding regions in EST sequences. Proc Int Conf Intell Syst Mol Biol I999, |38-| 48.

26. Conesa A, Gotz A, Garcia-Gomez JM, Terol J, Talon M and Robles M: Blast2Go: a universal tool for annotation, visualization and analysis in functional genomics research. Bioinformatics 2005, 21:3674-3676.

27. Nagaraj SH, Deshpande N, Gasser RB and Ranganathan S: ESTExplorer: an expressed sequence tag (EST) assembly and annotation platform. Nucleic Acids Research 2007, 35 WI43-WI47.

28. Ye J, Fang L, Zheng H, Zhang Y, Chen J, Zhang Z, Wang J, Li S, Li R, Bolund $L$ and Wang $\rfloor$ : WEGO: a tool for plotting GO annotations. Nucleic Acids Res 2006, 34(Web Server issue): W293-W297.

29. Durinck S, Moreau Y, Kasprzyk A, Davis S, De Moor B, Brazma A and Huber W: BioMart and Bioconductor: a powerful link between biological databases and microarray data analysis. Bioinformatics 2005, 21:3439-40.

30. Thompson JD, Gibson TJ, Plewniak F, Jeanmougin F and Higgins DG: The CLUSTAL $X$ windows interface: flexible strategies for multiple sequence alignment aided by quality analysis tools. Nucleic Acids Research 1997, 25:4876-4882.

31. Finn RD, Tate I Mistry J Cogrill PC Sammut JS, Hotz HR, Ceric G Forslund K, Eddy SR, Sonnhammer EL and Bateman A: The Pfam protein families database. Nucleic Acids Research 2008, 36: D28I-D288.

32. Nagasaki H, Arita M, Nishizawa T, Suwa M and Gotoh O: Speciesspecific variation of alternative spicing and transcriptional initiation in six eukaryotes. Gene 2005, 364:53-62

33. Chen FC, Chen CJ, Ho JY and Chuang TJ: Identification and evolutionary analysis of novel exons and alternative splicing events using cross-species EST-to-genome comparisons in human, mouse and rat. BMC Bioinformatics 2006, 7:136.

34. Deutsch $M$ and Long $M$ : Intron-exon structures of eukaryotic model organisms. Nucleic Acids Res 1999, 27:3219-3228.

35. Sugnet CW, Kent WJ, Ares M Jr and Haussler D: Transcriptome and genome conservation of alternative splicing events in humans and mice. Pac Symp Biocomput 2004, 66-77.

36. Roberts RM, Smith GW Bazer FW Cibelli J, Seidel GE Jr, Bauman DE, Reynolds LP and Ireland J: Farm animal research in crisis. Science 2009, 324:468-469. 
37. King AJ, Olivier NB, Mohankumar PS, Lee JS, Padmanabhan $V$ and Fink GD: Hypertension caused by prenatal testosterone excess in female sheep. American journal of physiology. Endocrinology and metabolism 2007, 292:EI837.

38. Padmanabhan V: Environment and origin of disease. Rev Endocr Metab Disord 2007, 8:67-69.

39. Rogers CS, Stoltz DA, Meyerholz DK, Ostedgaard LS, Rokhlina T, Taft PJ, Rogan MP, Pezzulo AA, Karp PH, Itani OA, Kabel AC, Wohlford-Lenane CL, Davis G], Hanfland RA, Smith TL, Samuel M, Wax D, Murphy CN, Rieke A, Whitworth K, Uc A, Starner TD, Brogden KA, Shilyansky J, McCray PB Jr, Zabner J, Prather RS and Welsh MI: Disruption of the CFTR gene produces a model of cystic fibrosis in newborn pigs. Science 2008, 321:1837.

40. Reynolds LP, Ireland JJ, Caton JS, Bauman DE and Davis TA: Commentary on domestic animals in agricultural and biomedical research: an endangered enterprise. Journal of Nutrition 2009, 139:427.

4I. Forrest ST, Barringhaus KG, Perlegas D, Hammarskjold ML and McNamara CA: Intron Retention Generates a Novel Id3 Isoform That Inhibits Vascular Lesion Formation. The Journal of biological chemistry 2004, 279:32897-32903.

\section{Publish with Bio Med Central and every scientist can read your work free of charge}

"BioMed Central will be the most significant development for disseminating the results of biomedical research in our lifetime. "

Sir Paul Nurse, Cancer Research UK

Your research papers will be:

- available free of charge to the entire biomedical community

- peer reviewed and published immediately upon acceptance

- cited in PubMed and archived on PubMed Central

- yours - you keep the copyright
BioMedcentral 